\title{
Effect of Tasmanian blue gum (Eucalyptus globulus Labill.) leaf extract on cowpea weevil (Callosobruchus maculatus [Fabricius, 1775], Coleoptera: Chrysomelidae)
}

\author{
Samuel Femi BABATUNDE ${ }^{1,2}$, Abdulrasak Kannike MUSA ${ }^{1}$
}

Received May 21, 2020; accepted November 27, 2020. Delo je prispelo 21. maja 2020, sprejeto 27. novembra 2020.

Effect of Tasmanian blue gum (Eucalyptus globulus Labill.) leaf extract on cowpea weevil (Callosobruchus maculatus [Fabricius, 1775], Coleoptera: Chrysomelidae)

Abstract: A laboratory study was carried out to examine the efficacy of solvent extract of Eucalyptus globulus leaves in reducing post-harvest losses caused by cowpea weevil (Callosobruchus maculatus) on cowpea seed variety RSH 256. $450 \mathrm{~g}$ of E. globulus leaf powder were put in $1000 \mathrm{ml}$ flask and $450 \mathrm{ml}$ of $\mathrm{n}$-hexane was used as the solvent. The extract was tested at dosages of 50,100 and $150 \mu \mathrm{l} \mathrm{g} \mathrm{g}^{-1}$ of cowpea grains on the weevil in stored cowpea. The different rates of treatment recorded significant differences $(p<0.05)$ in causing adult mortality compared to the untreated control. The different rates of treatment also recorded significant differences $(p<0.05)$ in emergence of F1 adults of each treatment compared to the control. The percentage masst loss and grain damage were also suppressed as a result of treatment with the plant material compared to the untreated control. However, among the treatments $150 \mu \mathrm{l} 150 \mathrm{~g}^{-1}$ cowpea recorded the highest adult mortality rate and lowest emergence while control had the lowest mortality rate and the highest emergence of the insect. The rates of application were indicative of bioactive characteristics of the plant extract.

Key words: cowpea; Callosobruchus maculatus; Eucalyptus globulus; leaf exctracts; biopesticides
Vpliv listnega izvlečka modrega evkalipta (Eucalyptus globulus Labill.) na skladiščnega hrošča Callosobruchus maculatus (Fabricius, 1775) (Coleoptera: Chrysomelidae)

Izvleček: Za preučitev učinkovitosti izvlečkov listov modrega evkalipta (Eucalyptus globulus) na zmanšanje skladiščnih izgub, ki jih povzroča hrošč Callosobruchus maculatus na semenu kitajske vinje ('RSH 256') je bil izveden laboratorijski poskus. $450 \mathrm{~g}$ zmletih listov modrega evkalipta je bilo v $1000 \mathrm{ml}$ steklenicah prelitih s $450 \mathrm{ml}$ topila n-heksana. Vpliv izvlečka je bil preiskušen $\mathrm{v}$ odmerkih 50,100 in $150 \mu \mathrm{l}$ na $50 \mathrm{~g}$ semena kitajske vinje, naseljenega s hroščem. Različni odmerki so povzročili značilne razlike $(p<0,05) \mathrm{v}$ smrtnosti hrošča $\mathrm{v}$ primerjavi s kontrolo. Različni odmerki so povzročili tudi značilne razlike $\mathrm{v}$ pojavljanju $(p<0,05)$ odraslih hroščev F1 rodu v primerjavi s kontrolo. Tudi odstotka izgube mase in poškodovanosti zrnja sta se zmanjšala kot posledica nanosa izvlečka listov modrega evkalipta v primerjavi s kontrolo. Med obravnavanji je imela uporaba $150 \mu \mathrm{l}$ izvlečka listov modrega evkalipta na 150 g semena kitajske vinje največji vpliv na smrtnost škodljivca in zmanjšanje pojavljanja imagov, medtem ko je bila njihova smrtnost $\mathrm{v}$ kontroli najmanjša, pojavljanje pa največje. Uporabljeni odmerki izvlečkov dokazujejo bioaktivne učinke modrega evkalipta

Ključne besede: kitajska vinja; Callosobruchus maculatus; Eucalyptus globulus; listni izvlečki; bioinsekticidi 


\section{INTRODUCTION}

Cowpea (Vigna unguiculata [L.] Walp.) is an edible legume crop in many parts of the world especially in tropical and subtropical regions. Cowpea belongs to the family Fabaceae (Singh, 2002). Cowpea is the most economically important indigenous African legume and is of vital importance to the livelihood of several millions of people in West and Central Africa (Langyntuo et al., 2003).

Cowpea plays a critical role in the lives of millions of people in Africa and other parts of the developing world, where it is a major source of dietary protein that nutritionally complements staple low-protein cereal and tuber crops, and is a valuable and dependable commodity that produces income for farmers and traders (Singh, 2002; Langyintuo et al., 2003).

Cowpea is a drought tolerant and short warmweather crop well adapted to the drier regions where other food legumes do not perform well. It requires annual rainfall of about 750-1100 mm (Hall et al., 2002; Hall 2004). As much as $1000 \mathrm{~kg} \mathrm{ha}^{-1}$ of dry grain has been produced in a Sahelian environment with only $181 \mathrm{~mm}$ of rainfall and high evaporative demand (Hall and Petal, 1985).

Several diseases, insect pests, nematodes, and parasitic weeds cause significant losses in cowpea yield on field and in storage (Iheanacho et al., 2000). Cowpea is susceptible to a number of fungal, bacterial and viral diseases such as leaf spot, ashy stem blight, bacterial blight, black-eyed cowpea mosaic potyvirus (BICMV), cowpea aphid-borne mosaic potyvirus (CABVC), and cowpea mosaic comovirus (CPMV) (Shaw, 1988). All of these factors, singly or combined are responsible for the low grain yield obtained from the cowpea fields (Singh, 2002). Control by one or two applications of insecticide is invariably necessary. Infestation of insect pest on cowpea for commercial production will lead to downgrading of grain (Monfankye, 2014).

There has however been serious concerns about the long-term negative effect of continued or excessive use of synthetic formulations in insect pest control (Praveen \& Dhandapani, 2001). The work therefore aims at evaluating the effect of Eucalyptus globulus Labill. leaf extract on cowpea weevil (Callosobruchus maculatus [Fabricius, 1775 ]).

\section{MATERIALS AND METHODS}

\subsection{EXPERIMENTAL SITE}

This study was conducted in the Department of
Crop Protection laboratory, and Ir. Leo Vande Mierop Biotechnology laboratory of the University of Ilorin. The extraction process was carried out in the Central Research and Diagnostic Laboratory, Tanke, Ilorin, Nigeria.

\subsection{SOURCE AND PREPARATION OF SEEDS}

The cowpea seed variety RSH 256 used was obtained from the International Institute of Tropical Agriculture (IITA), Ibadan, Oyo State, Nigeria. The seeds are white in colour with a maturity period of 60 days. The seeds were wrapped in a polyethylene bag and kept in the freezer compartment of a refrigerator in the Ir. Leo Vande Mierop Biotechnology laboratory, University of Ilorin, to kill immature stages of insects. The seeds were removed 10 days after freezing and then spread on a laboratory desk to thaw.

\subsection{INSECT CULTURE}

A culture of cowpea weevil, C. maculatus, was prepared at laboratory ambient temperature $\left(30 \pm 3^{\circ} \mathrm{C}\right)$ and relative humidity $(68 \pm 3 \% 0)$, respectively. The weevils were collected from already existing stock in the Crop Protection laboratory, University of Ilorin, Nigeria. Fifty (50) unsexed adults of $C$. maculatus were picked with the aid of hair brush to infest cowpea seeds in a transparent plastic container which was covered with muslin cloth held tightly by perforated lid to ensure aeration and prevent escape of the insects. Freshly emerged adults were used for the study.

\subsection{APPARATUS AND EQUIPMENT}

The apparatus, equipment and materials used include: transparent plastic containers, cowpea seeds, water, n-hexane, measuring cylinder, conical flasks, Eucalyptus globulus leaves, muslin cloth, a pair of scissors, a razor blade, paper tape, hair brush, digital weighing balance, spatula, micro-pipette $(0-200 \mu \mathrm{l})$, Soxhlet apparatus, a plastic sieve, electric blender, rubber band, laboratory desk, refrigerator, foil paper and beakers.

\subsection{COLLECTION AND PLANT IDENTIFICATION}

Mature leaves of Eucalyptus globulus were collected from the parent plant at the University of located in the southern Guinea Savannah agro-ecological zone of $\mathrm{Ni}$ geria between latitude $8^{\circ} 25^{\prime} \mathrm{N}$ and longitude $4^{\circ} 67^{\prime} \mathrm{E}$ in 
the morning at sunrise. The leaves were taken to Plant Biology Department of the University for for proper identification.

\subsubsection{Processing of the plant leaves}

Fresh mature leaves of E. globulus were air-dried, ground with the aid of electric blender, sieved by using a $2 \mathrm{~mm}$ sieve to obtain uniform particles. The powder was stored in a vial under room condition until required for use.

\subsubsection{Extraction process}

Extraction from the E. globulus leaf powder was done using the following methods:

Cold extraction, and Soxhlet extraction

Cold extraction:

$450 \mathrm{~g}$ of E. globulus leaf powder were put in $1000 \mathrm{ml}$ flask and $450 \mathrm{ml}$ of $\mathrm{n}$-hexane was used as the solvent. Mixture of the powder and the solvent was shaken thoroughly and allowed to settle for 4 days. The flask was covered with paper sellotape. The extract was separated from the sediment into a $1000 \mathrm{ml}$ beaker using a sieve and then placed on laboratory worktable for excess solvent to evaporate. The concentrated extract was kept in a vial until required for use in evaluating the insecticidal potential of the plant material.

\section{Soxhlet extraction:}

$150 \mathrm{~g}$ of E. globulus leaf powder was wrapped in a muslin cloth and tied with rubber band before introducing it into the thimble of a Soxhlet extractor. $300 \mathrm{ml}$ of $\mathrm{n}$-hexane was introduced into a round bottom flask. The electric cooker served as source of heat which lasted for 6-7 h. The excess solvent was allowed to evaporate in order to concentrate the extract. The extract remaining after evaporation was kept in a vial until required for use in the determination of bioactive components of the plant material.

\subsubsection{Determination of bioactive components of $E$. globulus leaves using $\mathbf{n}$-hexane extract}

Plant material consisted of leaves was put into distillation apparatus using Soxhlet apparatus. Mass of plant material was taken before loading in the Soxhlet apparatus and water is heated so that the steam passes through the plant material vaporizing the volatile compounds. The vapour flows through a coil where they condense back to liquid which is then collected in the receiving vessel.

\subsubsection{Experimental procedure}

$13 \mathrm{~g}$ of the sticky extract of E. globulus leaves was dissolved in $4 \mathrm{ml}$ of $\mathrm{n}$-hexane. The mixture was stirred with the aid of spatula. Different volumes of the concentration i.e., 50, 100 and $150 \mu$, were measured using a micro pipette. Aqueous extract of E. globulus leaves was added to $50 \mathrm{~g}$ cowpea seeds in transparent plastic containers at three levels, 50, 100 and $150 \mu \mathrm{l}$ using a micro-pipette. Each treatment was replicated three times including the untreated control. Ten freshly emerged adults of C. maculatus from the stock culture were added to the treated cowpea seeds in each plastic container and covered with muslin cloth held tightly with rubber band. The effect of the plant extract on the survival of adult C. maculatus was assessed by recording adult mortality on daily basis.

\subsection{DATA COLLECTION}

Data were collected on various parameters including adult mortality, total number of emerged progeny (adults), number and weight of damaged seeds (seeds with holes) and undamaged seeds (seeds without holes) and percentage seed weight loss, and average number of seeds per $50 \mathrm{~g}$ in a container. Counts of the emerged weevils commenced 23 days after infestation (DAI) and continued at intervals of $48 \mathrm{~h}$ until $100 \%$ adult emergence was recorded.

The percentage seed mass loss was computed following the method of Haines (1991) as follows:

$$
\frac{\text { Initial mass }- \text { Final mass }}{\text { Initial mass }} \times 100
$$

\subsubsection{Data analysis}

Data were subjected to analysis of variance using Genstat 12th edition and means were separated using Duncan`s Multiple Range test (DMRT) at 5\% level of significance

\section{RESULT AND DISCUSSION}

The results of the study revealed that the various treatments used in the experiment had effects on mortality increased with increase of dosages of extract. 
The E. globulus leaf extract caused adult mortality of $C$. maculatus at the high and low rates when compared to the control, which was indicative of bioactive characteristics of the plant part. This is in agreement with the report of Oluma and Garba (2002) that E. globulus has potential as source of insecticide for protection of stored grains against attack by C. maculatus. They concluded that E. globulus extract had toxicity against adults of $C$. maculatus. The extract used in this study could have caused insect mortality due to their physical action on respiration through blockage of the spiracles of the C. maculatus. The differences in the adult mortality could be attributed to the active ingredients of E. globulus extract. The shortcomings of the use of synthetic chemicals which include development of resistance by insects, adverse effect on non-target species, pollution of the environment including soil, water and air and hazard of residues necessitated the evolution of natural insecticides of plant origin (Deedat, 1994).

The E. globulus leaf extracts reduced progeny emergence of $C$. maculatus in treated cowpea seeds (Table 2). This could be attributed to the adult mortality already observed (Table 1) and the inhibition of oviposition as well as the remarkably high reduction in survival to adulthood of mature stages of $C$. maculatus compared to the control. This result corroborates that of Okonkwo and Ewete (1999) in pepper fruit, Ogunwolu and Idowu (1994) in root powders of Zanthoxylum spp. and neem seed.

The E. globulus leaf extract was also observed to have effects in reducing the damage on cowpea seeds by C. maculatus (Table 3). Damage on cowpea seeds may have been reduced as a result of the extracts acting as a deterrent to $C$. maculatus, keeping them from infesting and damaging the seeds. A similar trend of eucalyptus oil activity in preventing grain damaged to cowpea by C. maculatus was observed by Longe (2011).

The study reveals that E. globulus leaf extract could be very effective for use as biopesticides for protecting cowpea seeds from $C$. maculatus infestation and damage. It has been reported by the pest management specialists that botanicals are not known to leave any residue in any crop they are used to protect and the protective ability of essential oils could be attributed to interspecific insect responses to oil constituents (Enan, 2001)

The use of natural toxicants from plants as insecticides had been existent since the ancient times (Bohinc et al., 2013) and is investigated in recent times (Bohinc et al., 2020) The natural insecticides which require low cost to prepare, are readily available, environmentally and ecologically friendly are best suited for use in the storage of produce.

Table 1: Mean adult mortality of C. maculatus exposed to E. globulus leaf extract (x n out of 10)

\begin{tabular}{lllllllll}
\hline \multicolumn{1}{c}{ Adult mortality of C. maculatus (DAT) } \\
\hline E. globulus leaf extract $(\mu \mathrm{l})$ & 1 & 2 & 3 & 4 & 5 & 6 & 7 & 8 \\
\hline 50 & $1.33^{\mathrm{b}}$ & $3.33^{\mathrm{b}}$ & $4.33^{\mathrm{b}}$ & $6.33^{\mathrm{b}}$ & $7.67^{\mathrm{b}}$ & $\mathrm{b} 8.67^{\mathrm{b}}$ & $9.33^{\mathrm{b}}$ & 10.00 \\
100 & $3.00^{\mathrm{a}}$ & $5.67^{\mathrm{a}}$ & $7.67^{\mathrm{a}}$ & $9.33^{\mathrm{a}}$ & $9.67^{\mathrm{a}}$ & a $10.00^{\mathrm{a}}$ & $10.00^{\mathrm{a}}$ & 10.00 \\
150 & $3.33^{\mathrm{a}}$ & $6.00^{\mathrm{a}}$ & $8.00^{\mathrm{a}}$ & $9.67^{\mathrm{a}}$ & $10.00^{\mathrm{a}}$ & $10.00^{\mathrm{a}}$ & $10.00^{\mathrm{a}}$ & 10.00 \\
Control & $0.00^{\mathrm{b}}$ & $0.00^{\mathrm{b}}$ & $0.00^{\mathrm{c}}$ & $0.00^{\mathrm{c}}$ & $0.00^{\mathrm{c}}$ & $0.00^{\mathrm{c}}$ & $0.00^{\mathrm{c}}$ & 00.00 \\
S.E.M & 0.55 & 0.80 & 0.94 & 0.41 & 0.24 & 0.33 & 0.17 & Ns \\
\hline
\end{tabular}

Values with the same superscript in the same column are not significantly different at $5 \%$ level of significance using Duncan `s multiple range test. DAT: Days after treatment

Table 2: Effect of cowpea seeds treated with E. globulus leaf extract on progeny emergence of Callosobruchus maculatus

\begin{tabular}{llllllll}
\hline \multicolumn{7}{c}{ Progeny } & emergence of C. maculatus $(D A T)$ \\
\hline E. globulus leaf extract $(\mu \mathrm{l})$ & 23 & 25 & 27 & 29 & 31 & 33 & 35 \\
\hline 50 & $2.00^{\mathrm{a}}$ & $3.00^{\mathrm{ab}}$ & $2.33^{\mathrm{a}}$ & $3.67^{\mathrm{ab}}$ & $4.67^{\mathrm{a}}$ & $3.33^{\mathrm{a}}$ & $1.00^{\mathrm{a}}$ \\
100 & $0.33^{\mathrm{b}}$ & $3.00^{\mathrm{ab}}$ & $3.33^{\mathrm{a}}$ & $2.67^{\mathrm{b}}$ & $3.33^{\mathrm{a}}$ & $1.33 \mathrm{a}$ & $0.00^{\mathrm{b}}$ \\
150 & $0.33^{\mathrm{b}}$ & $1.33^{\mathrm{b}}$ & $2.00^{\mathrm{a}}$ & $2.00^{\mathrm{b}}$ & $2.67^{\mathrm{a}}$ & $0.33 \mathrm{a}$ & $0.00^{\mathrm{b}}$ \\
Control & $2.67^{\mathrm{a}}$ & $4.33 \mathrm{a}$ & $4.33^{\mathrm{a}}$ & $6.00^{\mathrm{a}}$ & $4.00^{\mathrm{a}}$ & $2.00^{\mathrm{a}}$ & $0.00^{\mathrm{ab}}$ \\
S.E.M & 0.41 & 0.62 & 0.82 & 0.80 & 0.76 & 0.87 & 0.289 \\
\hline
\end{tabular}

Values with the same superscript in the same column are not significantly different at $5 \%$ level of significance using Duncan 's multiple range test DAT: Days after treatment 
Effect of Tasmanian blue gum (Eucalyptus globulus Labill.) leaf ... (Callosobruchus maculatus [Fabricius, 1775], Coleoptera: Chrysomelidae)

Table 3: Effect of cowpea seeds treated with Eucalyptus globulus leaf extract on Callosobruchus maculatus activity

\begin{tabular}{|c|c|c|c|c|c|}
\hline \multicolumn{6}{|c|}{ Callosobruchus maculatus infestation } \\
\hline $\begin{array}{l}\text { E. globulus leaf extract } \\
(\mu \mathrm{l})\end{array}$ & $\begin{array}{l}\% \text { Seed mass } \\
\text { loss }\end{array}$ & $\begin{array}{l}\text { Mass of } \\
\text { damaged seeds }\end{array}$ & $\begin{array}{l}\text { Mass of } \\
\text { undamaged seeds }\end{array}$ & $\begin{array}{l}\text { Number of } \\
\text { damaged seeds }\end{array}$ & $\begin{array}{l}\text { Number of } \\
\text { undamaged seeds }\end{array}$ \\
\hline 50 & $18.3^{\mathrm{b}}$ & $17.8^{\mathrm{a}}$ & $23.1^{\mathrm{ab}}$ & $100.3^{\mathrm{ab}}$ & $108.3^{\mathrm{a}}$ \\
\hline 100 & $15.9^{\mathrm{b}}$ & $15.8^{\mathrm{a}}$ & $26.2^{\mathrm{a}}$ & $86.3^{\mathrm{b}}$ & $130.0^{\mathrm{a}}$ \\
\hline 150 & $12.3^{\mathrm{b}}$ & $15.8^{\mathrm{a}}$ & $22.7^{\mathrm{ab}}$ & $77.3^{\mathrm{b}}$ & $136.0^{\mathrm{a}}$ \\
\hline 0 & $31.4^{\mathrm{a}}$ & $20.0^{\mathrm{a}}$ & $16.0^{\mathrm{b}}$ & $131.3^{\mathrm{a}}$ & $74.7^{\mathrm{b}}$ \\
\hline S.E.M & 2.52 & 3.01 & 2.54 & 10.01 & 10.28 \\
\hline
\end{tabular}

Values with the same superscript in the same column are not significantly different at $5 \%$ level of significance using Duncan`s multiple range test.

\section{CONCLUSION}

Botanical control is said to be the best pest control of stored grain pests because it is biodegradable, environmentally friendly and does not leave toxic residues. Therefore, plant extracts can be another source of insecticides/pesticides against stored grain pests. The result from this research shows that Eucalyptus globulus have insecticidal potential for protecting stored cowpea against C. maculatus. The E. globulus extract prove to be effective on adult mortality. Furthermore, $150 \mu$ was the most effective and this was shown in the suppression of progeny emergence. Thus farmers can use E. globulus extract in place of expensive synthetic pesticides used against the cowpea weevil.

\section{REFERENCES}

Adebayo, T. \& Gbolade, A. A. (1994). Protection of stored cowpea from Callosobruchus maculatus using plantproducts. Insect Science and its Application, 15, 185-189. https://doi. org/10.1017/S1742758400015435

Bohinc, T., Horvat, A., Ocvirk, M., Košir, I. J., Rutnik, K., \& Trdan, S. (2020). The first evidence of the insecticidal potential of plant powders from invasive alien plants against rice weevil under laboratory conditions. Applied Sciences, 10(21), 7828. https://doi.org/10.3390/app10217828

Bohinc, T., Vayias, B., Bartol, T. (2013). Assessment of insecticidal efficacy of diatomaceous earth and powders of common lavender and field horsetail against bean weevil adults. Neotropical Entomology, 42, 642-648. https://doi. org/10.1007/s13744-013-0168-7

Deedat, Y.O. (1994). Problems associated with the use of pesticides: an overview. Journal of Agricultural Science, 93,735747.

Enan E (2001) Insecticidal activity of essential oils: octopaminergic sites of action. Comparative Biochemistry and Physiology, 130, 325-337. https://doi.org/10.1016/S15320456(01)00255-1

Enan, E.E. (2004). Molecular and pharmacological analysis of an octopamine receptor from American cockroachand fruit fly in response to plant essential oils. Archives of Insect Biochemistry and Physiology, 59, 161-171. https://doi. org/10.1002/arch.20076

Haines, C.P. (1991). Insect and Arachnids of tropical Stored Products: Their biology and identification. A laboratory manual (second edition). Storage Department, Tropical Development and Research Institute, London. $286 \mathrm{pp}$

Hall, A.E. and Patel, P.N. (1985). Breeding for resistance to drought and heat, in: Singh S.R. and Rachie K.O.(eds). Cowpea Research, Production and Utilization. Wiley, New York, pp 137-151.

Hall, A.E., (2004). Breeding for adaptation to drought and heat in cowpea European Journal of Agronomy, 21, 447-454. https://doi.org/10.1016/j.eja.2004.07.005

Hall, A.E., Ismail, A.M., Ethlers, J.D., Marfo, K.O., Cisse, N., Thiaw, S. and Close, T.J. (2002). Breeding cowpeas for tolerance to temperature extremes and adaptation to drought. In: Fatokun C.A, Tarawali S.A, Singh B.B, Kormawa P.M, Tamo M (eds) Challenges and Opportunities for Enhancing Sustainable Cowpea Production.International Institute of Tropical Agriculture, Ibadan, Nigeria. Pp 14-21.

Iheanacho, A.C., Olukosi, J.O., and Ogungbile A.O.(2000). EconomicEfficiency of Resource Use in Millet-basedCropping systems in Borno State of Nigeria. NigerianJournal of Tropical Agriculture, 2, 23-34.

Isman, M.B. (2008). Botanical insecticides: for richer, for poorer. Pest Management Science, 64, 8-11. https://doi. org/10.1002/ps.1470

Langyintuo, A. S., Lowenberg-DeBoer, J., Faye, M., Lambert,D., Ibro, G., Moussa, B., Kergna, A., Kushwaha, S.,Musa, S. \& Ntoukam, G. (2003). Cowpea supply and demand in West and Central Africa. Field Crops Research, 82, 215-231. https://doi.org/10.1016/S0378-4290(03)00039-X

Longe, O.O. (2011). Investigations into fumigant effect of commercially produced eucalyptus oil and Eugenia aromatica dust against Callosobruchus maculatus (Fabricius). 2010 International Conferenceon Biology, Environment and ChemistryIPCBEE.IACSIT Press, Singapore, 1. 439-442.

Monfankye R., (2014).The management of field pests on Cowpea (Vigna unguiculata (L.) Walp.) using botanicals [tobacco (Nicotiana tabacum) leaves, neem (Azadirachta indica) leaves, ginger (Zingiber officinale) rhizomes and onion ( $\mathrm{Al}$ lium cepa) bulbs]. Master of Science (Environmental Sci- 
ence), Kwame Nkrumah University of Science and Technology, Ghana, 85p.

Ogunwolu, O., and Idowu, O. (1994). Potential of powdered Zanthoxylum zanthoxyloides (Rutaceae) root bark and Azadirachta indica (Meliaceae) seed for the control of the cowpea seed bruchid, Callosobruchus maculatus (Bruchidae) in Nigeria. Journal of African Zoology, 108.

Okonkwo, E. U., and Ewete, F. K. (1999). Toxicity of Dennettia tripetala and Piper guineense seed powders and oils against Callosobruchus maculatus Fabricius (Coleoptera: Bruchidae) and Sitophilus zeamais Motscchulsky (Coleoptera: Curculionidae) in Nigeria. Journal of Herbs, Spices and Medicinal Plants, 1, 1-8.

Oluma, H.O.A. and Garba, I.U. (2002).Screening of Eucalyptus globulus and Ocimum gratissimum (Clocimum) for fungi- toxic properties against Pythium aphanidermatum. Nigerian Journal Biotechnology, 13, 49-54.

Shaw, R.H. (1988). Climatic requirement. pp. 609-638. In: G.F.Sprague (Ed.), Corn and corn improvement, AgronomyMonograph No 18 ASA-CSSA-SSSA, Madison, Wisconsin, USA. https://doi.org/10.2134/agronmonogr18.3ed.c10

Singh, B.B. (2002). Recent genetic studies in cowpea. In: Fatokun C.A., Tarawali, S.A., Singh, B.B., Kormawa, P.M., Tamo, M. (eds). Challenges and Opportunities for Enhancing Sustainable Cowpea Production. International Institute of Tropical Agriculture. Ibadan, Nigeria. Pp 3-13.

Praveen, P.M., \& N. Dhandapani (2001). Eco-friendly management of major pests of okra (Abelmoschus esculentus (L.) Moench), Journal of Vegetable Crop Production, 7(2), 3-12. https://doi.org/10.1300/J068v07n02_02 